\title{
Ayağın sık görülen dermatolojik sorunları
}

\section{Common dermatologic problems of foot}

\author{
Zeynep Topkarcı ${ }^{1}$, Rıfkiye Küçükoğlu² \\ ${ }^{1}$ Sağlık Bakanlığı, Bakırköy Dr. Sadi Konuk Eğitim Araştırma Hastanesi, Dermatoloji Kliniği, İstanbul, Türkiye \\ ${ }^{2}$ Isstanbul Üniversitesi, İstanbul Tıp Fakültesi, Deri ve Zührevi Hastalıklar Anabilim Dalı, İstanbul, Türkiye
}

Ayak vasküler, nörolojik, dermatolojik ve kas-iskelet organ sistemleri içeren, vücudun karmaşık bir bölgesidir. Ayak, bazı hastalıklar için bir bulgu veya semptomun görüldüğü ilk yer olabilir. Bu makalede, ayağın sık görülen dermatolojik sorunları tanı, ayırıcı tanı ve tedavi seçenekleri yönünden tartışılacaktır.

Anahtar sözcükler: ayak; dermatoloji; ayak hastalıkları
The foot is a complex region of the body that includes the vascular, neurologic, dermatologic, and musculoskeletal organ systems. The foot can be the first place for some diseases where its signs or symptoms appear. In this article, the diagnosis, differential diagnosis and treatment options of common dermatologic problems of the foot will be discussed.

Key words: foot; dermatology; foot diseases
D eri vücudun en büyük organıdır ve deri hastalıkları karşımıza kliniği benzer olsa da farkI isimlerle anılan birçok klinik tablo ile çıkar. Leonardo da Vinci'nin “Ayak, 26 kemik, 114 bağ ve 20 kastan oluşan bir sanat eseridir." tanımıyla, anatomik olarak bakıldığında karşımıza çıkan bu sanat eserini saran deride, genetik, infeksiyöz, mekanik ve bazen de derinin kendine has nedeni bilinemeyen hastalıkları ile farklı klinik tablolar görülebilir. Bu derlemede, ayağın sık görülen dermatolojik sorunlarından bahsedilecektir (Tablo 1).

\section{EKZEMALAR}

Atopik dermatit, dishidrotik ekzema ve kontakt dermatit ayağın sık görülen ekzematöz lezyonları arasında yer alır.

Atopik dermatit, erişkinde el ve/veya ayaklarda difüz, kaşıntılı, eritemli, skuamlı lezyonlar şeklinde görülebilir.

Dizhidrotik ekzemada klinik lezyonlar, ayak başparmakları ve el parmakları boyunca görülen, kaşıntılı mikroveziküllerdir. Döküntü zamanla papüloskuamöz karakter alabilir.

Kontakt dermatitler, irritan ve alerjik olmak üzere iki tiptir. İrritan kontakt dermatit (IKD), deriye temas eden kimyasal maddeler veya fiziksel travmanın etkisi ile herkeste gelişebilen, immünolojik olmayan deri inflamasyonu iken alerjik kontakt dermatit (AKD), çevresel alerjenlerle karşılaşma sırasındaki duyarlanmayı izleyerek gelişen inflamatuvar bir deri hastalığıdır.

iKD'de, akut gelişen olgularda yanma, batma ve hafif kaşıntı eşlik eder ve genellikle ayak dorsumunda, eritem, ödem, deride soyulma, vezikül ve erozyonlar görülür. İritanla temastan 4-6 hafta sonra iyileşir. AKD'de ise lezyonlar daha yaygındır, kaşıntı belirgindir ve alerjenle temastan birkaç gün ile bir hafta sonra iyileşir (Şekil 1). Kronik kontakt dermatitli olgularda iyi sınırlı skuam, eritem, hiperkeratoz ve çatlaklar görülebilir. AKD'de etken olarak en sık ayakkabı yapımında kullanılan lastik ve deri tespit edilir. Tedavide en önemli yöntem hastanın eğitimi ile irritanlardan ve tespit edilen alerjen maddelerden korunmadır. Ekzematöz lezyonların tamamında ayırıcı tanıda palmoplantar püstüler psöriazis, veziküler tinea pedis, skabiyez ve herpes simpleksi düşünmek gerekir. Tedavide nemlendiriciler, topikal steroidler, kaşıntı için sistemik antihistaminikler, veziküller büyük ve yaygınsa ıslak pansumanlar ve gereğinde sistemik steroidler kullanılabilir.

- İletişim adresi: Uz. Dr. Zeynep Topkarcı, Bakırköy Dr. Sadi Konuk Eğitim ve Araştırma Hastanesi, Dermatoloji Kliniği, Bakırköy, İstanbul Tel: 0533 - 5194244 e-posta: ztopkarci@yahoo.com

- Geliş tarihi: 16 Eylül $2013 \quad$ Kabul tarihi: 12 Kasım 2013 
Tablo 1. Ayağın dermatolojik sorunları

\begin{tabular}{|c|c|c|c|c|}
\hline Ekzema & $\begin{array}{l}\text { Papüloskuamöz } \\
\text { hastalıklar }\end{array}$ & $\begin{array}{l}\text { Infeksiyonlar ve } \\
\text { infestasyonlar }\end{array}$ & Genetik & $\begin{array}{l}\text { Mekanik } \\
\text { hasarlar }\end{array}$ \\
\hline Atopik dermatit & Psöriazis & Bakteriyel & Epidermolizis bülloza & Yanık \\
\hline Dizhidrotik ekzema & $\begin{array}{l}\text { Püstüler } \\
\text { bakterit }\end{array}$ & Viral & Palmoplantar keratoderma & Dekübit ülseri \\
\hline \multirow[t]{3}{*}{ Kontakt dermatit } & Liken planus & Fungal & Knuckle pads & Nöropatik ülser \\
\hline & Pitriazis rubra pilaris & Diğer & & Pernio \\
\hline & & & & Yabancı cisim \\
\hline $\begin{array}{l}\text { Selim } \\
\text { oluşumlar }\end{array}$ & $\begin{array}{l}\text { Malin } \\
\text { tümörler }\end{array}$ & $\begin{array}{l}\text { Vasküler } \\
\text { hastalıklar }\end{array}$ & $\begin{array}{l}\text { Sistemik ve } \\
\text { metabolik hastalıklar }\end{array}$ & \\
\hline Nasır & Malin melanom & Lökositoklastik vaskülit & Diyabetik ayak & \\
\hline Nevus & Skuamöz hücreli karsinom & Livedoid vaskülit & Tendinöz ksantom & \\
\hline Piyojenik granülom & Diğer & Piyoderma gangrenozum & & \\
\hline Siyah topuk & & Pigmente purpurik dermatoz & & \\
\hline Koenen tümörü & & Vazomotor hastalıklar & & \\
\hline \multirow[t]{3}{*}{ Diğer } & & Trombotik-embolik hastalıklar & & \\
\hline & & Soğuk agglütininler & & \\
\hline & & Vasküler yetmezlik & & \\
\hline
\end{tabular}

\section{PAPÜLOSKUAMÖZ HASTALIKLAR}

Psöriazis, primer deri lezyonu iyi sınırlı, sedefimsi renkte skuamla kaplı, kalın, eritematöz plak olan derinin kronik inflamatuvar hastalığıdır. Psöriazis plağının kabukları kaldırılınca noktasal kanama odaklarının görülmesi (Auspitz belirtisi) tanıda yardımcıdır. Ayaklardaki psöriazis lezyonları aşırı hiperkeratozla seyredebilir (Şekil 2). Psöriazisli olgularda \%50'ye varan sıklıkta, değişik şiddetlerde tırnak tutulumu görülür. Piting, onikoliz, subungual keratoz, kaba tırnak distrofisi, paronişi, yatay çizgilenme ve splinter hemoraji gibi tablolara yol açabilir. Tutulan tırnak sayısı, şekli ve şiddeti farklı olabilir. Tedavide birinci basamak topikal steroidlerdir. Tek başına yeterli olmadıkları durumda, katran, D vitamini, retinoik asit ve türevlerini içeren topikal tedaviler de kullanılabilir. Ayakta şiddetli psöriazisi olan hastalarda, lokal PUVA (psoralen + ultraviyole $A)$, gereğinde sistemik tedaviler de

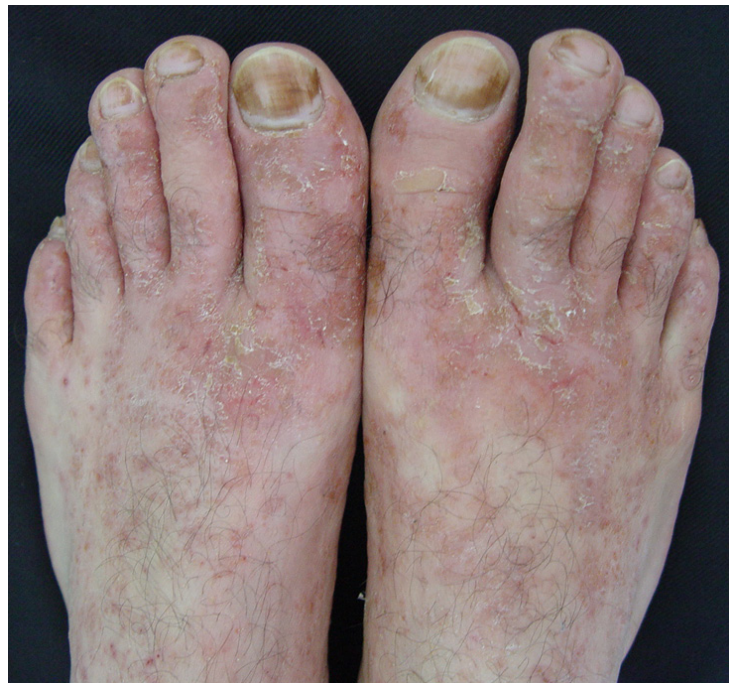

Şekil 1. Alerjik kontakt dermatit.

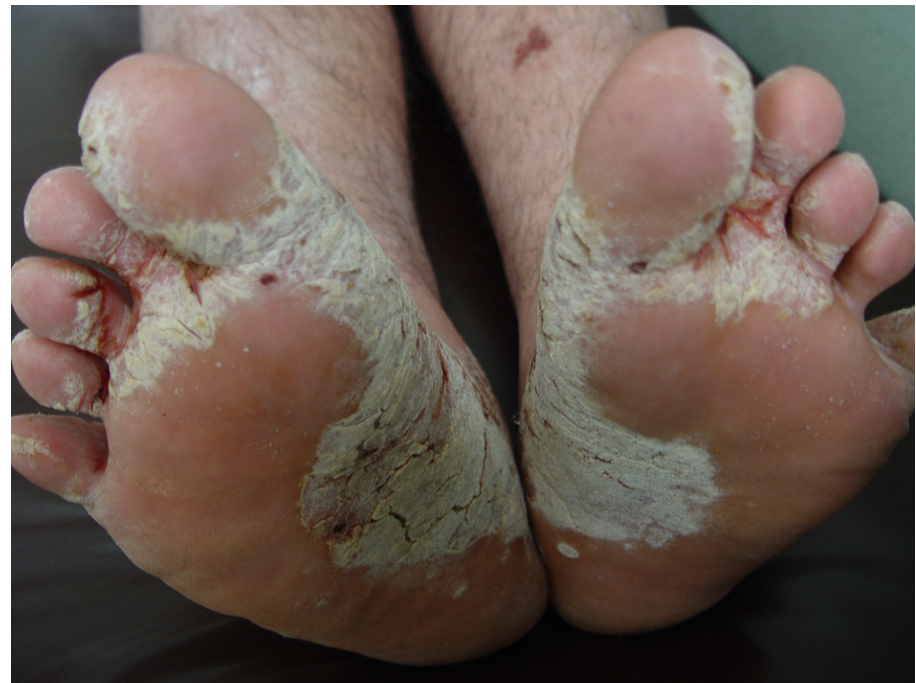

Şekil 2. Psöriazis. 
kullanılabilir (metotreksat, asitretin, siklosporin veya biyolojik ajanlar).

Püstüler bakterid, palmoplantar bölgede yerleşen ve steril püstüllerle seyreden kronik bir dermatozdur. Lokalize püstüler psöriazisin hafif bir formu veya çeşitli infeksiyonlara karşı bir id reaksiyonu olabileceği düşünülmektedir. Ancak infeksiyon ile ilişkisi tanımlanmamıştır. Çoğunlukla avuç içi ve ayak tabanları simetrik tutulur. Yanma, batma, kaşıntı olabileceği gibi asemptomatik de olabilir. Yeni püstüller çıkarken, eskileri kısa sürede koyu kırmızı maküllere ve sarımsı kahverengi krutlara dönüşür. Tedavide kombine olarak kullanılan sistemik antibiyotikler (tetrasiklin) ve topikal steroidlerle olumlu sonuç alınabilir. Dirençli olgularda elayak PUVA'sı ve sistemik retinoik asit (asitretin) tedavi seçenekleridir.

Pitriasis rubra pilaris (PRP), nadir görülen bir deri hastalığıdır ancak lezyonları, sıklıkla ayak taban ve parmaklarında görülür. Ayak taban ve parmakları masif hiperkeratoza bağlı balmumu görünümdedir (Şekil 3). Psöriazis ile karışabilir. Tedavide metotreksat ve retinoik asit kullanılır.

Liken planus, çok sayıda poligonal, morumsu, yassı papüllerle karakterize deri hastalığıdır. En sık görülen yerler ayak bileği ve el bileklerinin dorsal alanlarıdır (Şekil 4). Nadir görülen bir formu olan hiperkeratozik liken planus, genellikle tibia ön yüzde görülür. Tedavi edilmezse, kronik inflamasyona bağlı olarak bu alanda skuamöz hücreli karsinom gelişimi gözlenebilir. Liken planus tedavisinde, topikal kortikosteroid ve yoğun kaşıntı olması nedeni ile antihistaminik kombinasyonu kullanılır. Daha yaygın lezyonlu olgularda, kısa süreli sistemik steroid ve PUVA tedavisi etkilidir.

\section{SELIM OLUŞUMLAR}

Nasır (kallus-klavus), ayakta en sık görülen hiperkeratozik deri lezyonlarıdır. Genellikle kemik çıkıntılarına denk gelen basınç alanlarında sürtünme, çarpma gibi tekrarlayan minör travmalara bağlı olarak gelişen akantoz ve hiperkeratozun oluşturduğu bölgesel deri kalınlaşmasıdır. Klavus ve kallus şeklinde tipleri vardır. Klavus, özellikle uymayan dar ayakkabılar veya ekzositoz ve deformite gibi ayak kemikleri ile ilgili patolojik değişikliklere bağlı olarak gelişir. Ayak beşinci parmak dorsolaterali tipik yerleşim yeridir (Şekil 5). Keskin sınırlı olup merkezinde sivri, koni biçiminde, sert, beyaz merkezi çekirdek ve çevresinde geniş, yarı saydam, sarımsı renkli hiperkeratozik alan bulunur. Özellikle temasla artan ağrı vardır. Ayak tabanı da sık yerleşim yerlerindendir. Bu bölgede verruca plantaris ile ayırıcı tanıya girer. Merkezinde öz bölgesinin varlığı, deri çizgilerinin korunması, kırmızı siyah noktacıklar şeklinde kanama

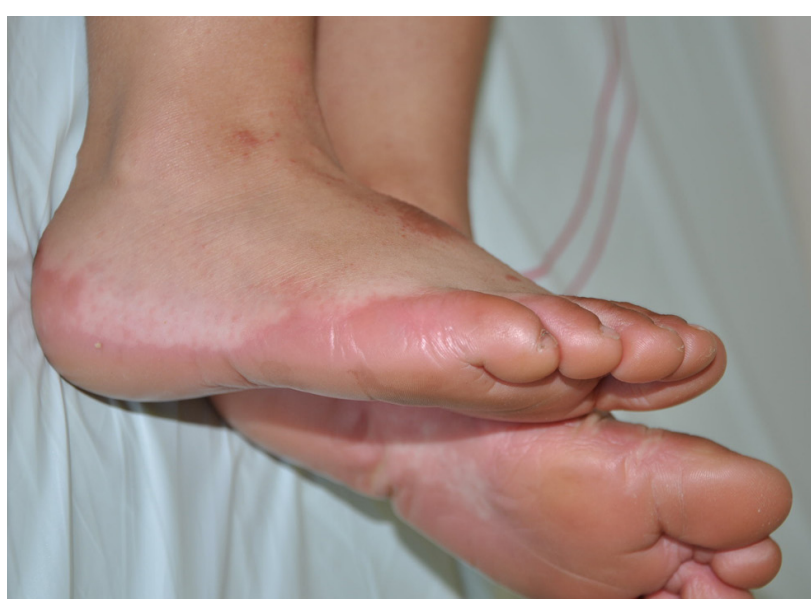

Şekil 3. Pitriazis rubra pilaris.

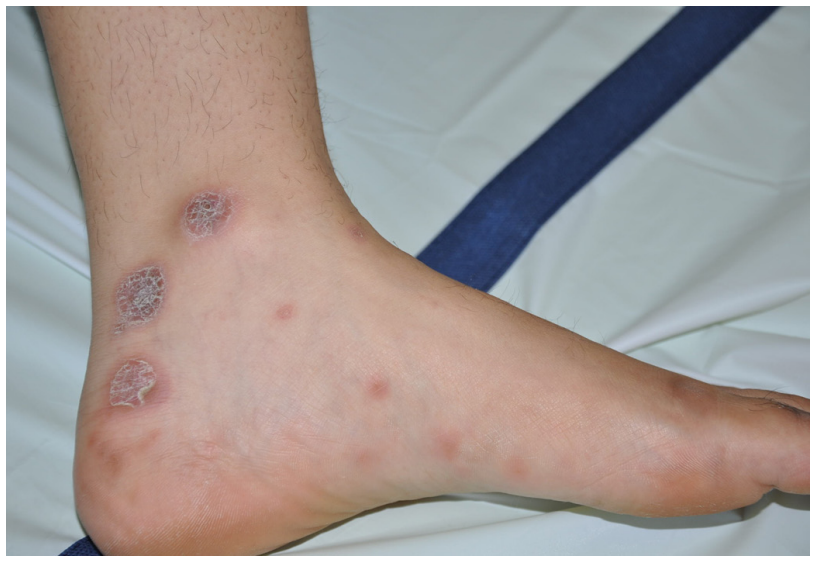

Şekil 4. Liken planus.

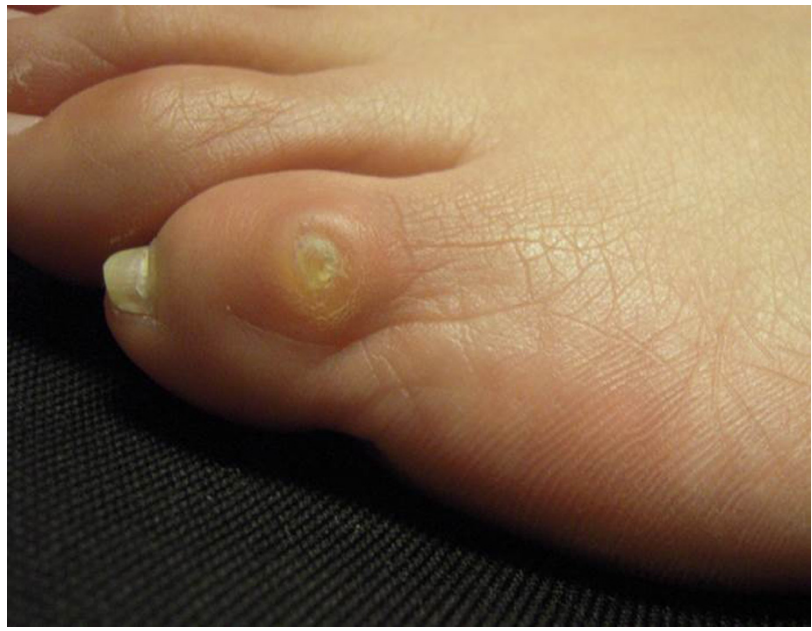

Şekil 5. Klavus.

alanları içermemesi, yanlardan sıkma değil, üzerine basma ile ağrı olması klavus lehinedir. Tedavide, öncelikle altta yatan mekanik nedeni ortadan kaldırmak gerekir. Keratolitikler, koterizasyon, kriyoterapi, gerekli olgularda cerrahi eksizyon yapılabilir. 
Klavusun ayak parmak aralarında yerleşen özel tipine yumuşak korn denir. Fazla keskin sınırlı değildir ve maserasyona bağlı, beyaz renkli, hafif kabarık plak şeklinde görülür. Sekonder infeksiyon gelişebilir. Interdigital tinea pedis'ten sert olmaları ile ayırt edilir. Lezyonlu bölgeye bir süre, simit şeklinde, koruyucu yumuşak silikon yastık kullanımı ile lezyon genellikle geriler.

Kallus, klavusa göre daha yassı, fazla keskin sınırı olmayan, kirli sarı renkte ve merkezde öz içermeyen, hiperkeratozik plaklardır (Şekil 6). Deride bölgesel kalınlaşma görülür. Ortopedik sorunlar, uymayan ayakkabılar en önemli nedenlerdir. Düzenli namaz kılanlarda diz ve ayak bileklerinde kallus oluşur (namaz topağı). Kallusta kalın skuam ve mum lekesi bulgusunun olmaması psöriazisten ayırır. Kronik lezyonlarda, abseleşme ve fissürleşme gibi komplikasyonlar gelişebilir. Tedavisi klavus ile aynıdır.

Nevüsler, derinin sık görülen lezyonlarındandır. Birçok kişide nevüsler, vücudun üst taraflarında bulunurken, aynı zamanda alt ekstremitelerde ve ayaklarda da bulunabilir.

Nevüs hücrelerinin sadece epidermisin alt kısmına yerleştiği junctional nevüslerin (Şekil 7a) avuç içi ve ayak tabanı lezyonları, akral lentijinöz malin melanomun (Şekil 7b) başlangıç lezyonu ile ayırıı tanıya girer. Şüphe halinde biyopsi veya total eksizyonu şarttır.

Piyojenik granülom, lobüler kapiller hemanjiyom olarak da isimlendirilen selim, travmaya bağlı gelişen kapiller proliferasyondur. Gebelikte oluşma olasılı̆̆ı yüksektir. Bakteriyel bir hastalık değildir; ancak, deride

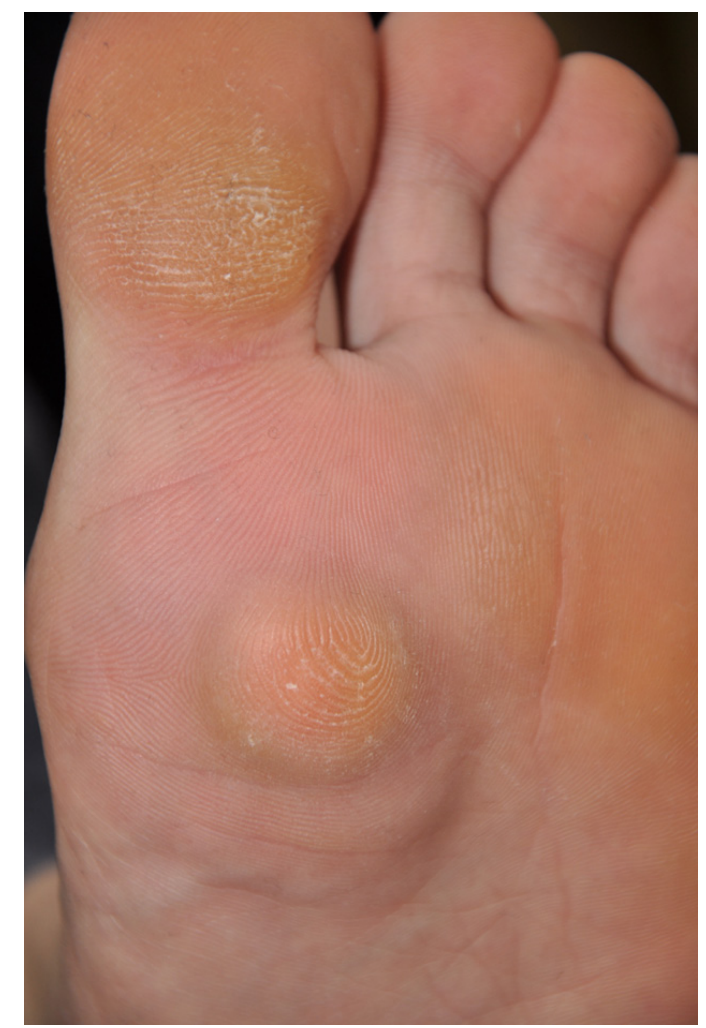

Şekil 6. Kallus.

bakteriyel infeksiyon alanında ortaya çıkabilmektedir. Pembe-kırmızı renkte, bazen saplı olabilen papüller şeklindedir. Kolay kanama özelliği vardır. Ayakta
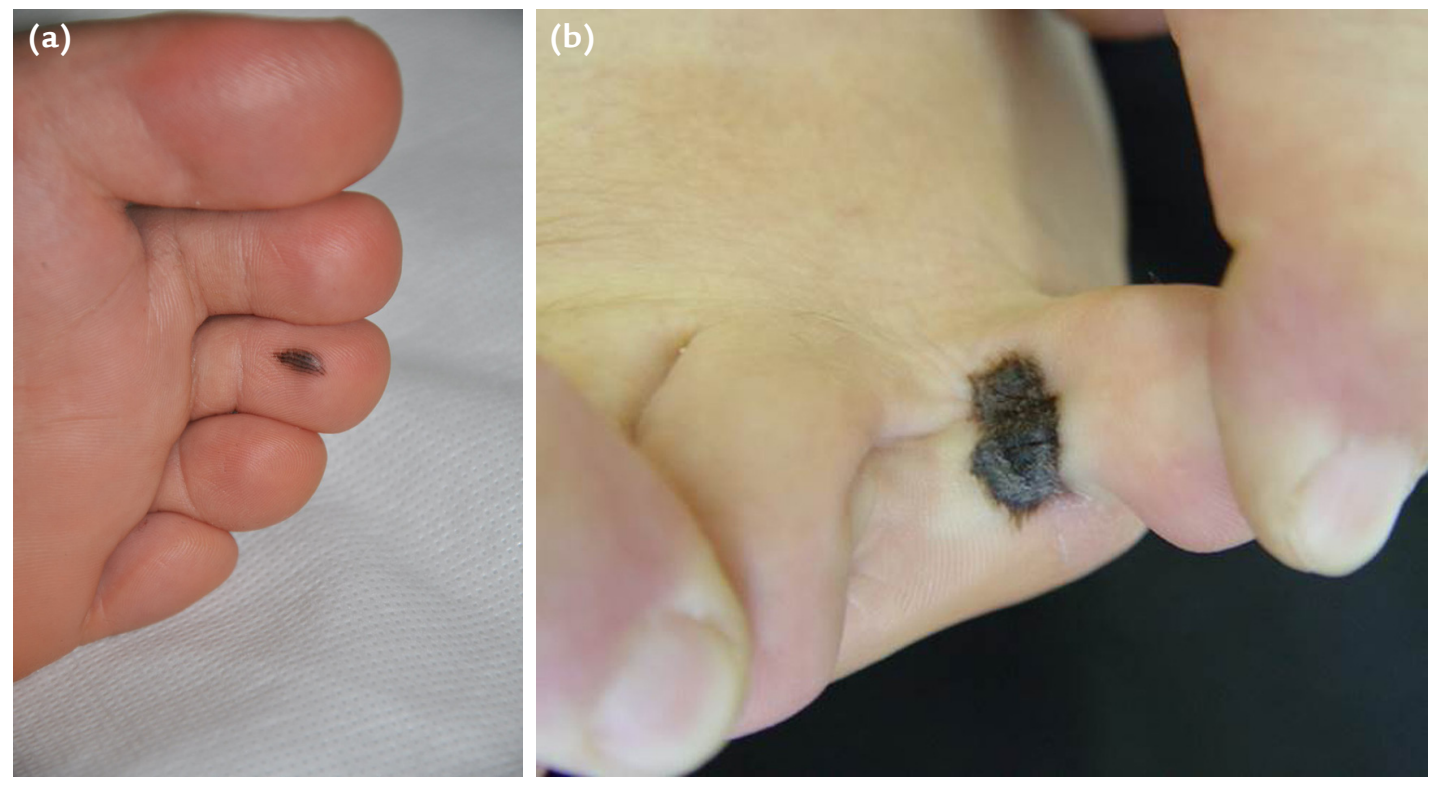

Şekil 7. a, b. Junctional nevüs (a). Akral lentijinöz malin melanom (b). 
görülmesinin en sık sebeplerinden biri tırnak batmasıdır. Ayaktaki lezyonlarda ayırıcı tanıda, anjiyom, ekrin poroma, skuamöz hücreli karsinom, malin melanom ve yabancı cisim granülomu yer alır. Tedavisinde cerrahi, elektrokoterizasyon, kriyoterapi ve pulse dye lazeri kullanılmaktadır.

Siyah topuk, selim, asemptomatik bir lezyondur. Illk kez "kalkaneal peteşi” şeklinde tanımlanmıştır. Siğil ve melanom ile karışabilir. Klinik olarak, küme oluşturan koyu kırmızıdan kahverengiye değişen renklerde benekler şeklindedir. Lezyonlar, basketbol ve tenis gibi sporları yapanlarda ayak tabanına gelen travma sonucu oluşur. Pigmentasyon stratum korneum'da kuruyan kanın sonucunda oluşur. Lezyon ufak bir bistüri ile kolayca çıkartılabilir.

Koenen tümörü (periungual fibrom), tüberosklerozda görülen, periungual veya subungual yerleşimli, histopatolojik olarak anjiyofibrom yapısında selim tümördür. Genellikle ergenlik döneminde ortaya çıkar. Ayak parmaklarında ele göre daha sıktır (Şekil 8). Tırnak plağı ile tırnak kıvrımı arasındaki bölgede olması tipiktir. Çoğunlukla birkaç milimetre çapında, pembe veya deri renginde, düzgün yüzeyli, sert, çıkıntılı, asemptomatik, tek veya çoklu papüller şeklindedir. Tırnak plağında dikey oluklar veya onikolize yol açabilir. Yaşam boyu yeni lezyonlar çıkabilir. Malin dönüşüm yoktur. Tedavide cerrahi eksizyon yapılabilir ama nüks sıktır.

\section{MALIN TÜMÖRLER}

Malin melanom (MM), nöral yarık kökenli melanositlerden ve melanositlerin farklılaşması ile oluştuğu düşünülen nevüs hücrelerinden kaynaklanan bir

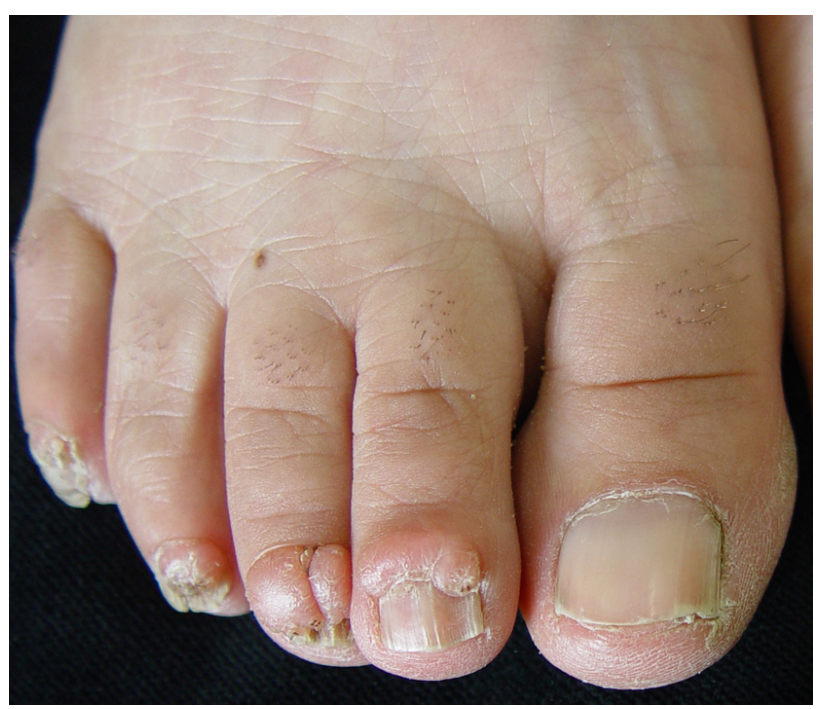

Şekil 8. Periungual fibrom (Koenen tümörü). neoplazmdır. Beyaz ırkta ve orta yaş grubunda daha sık görülür. Klinik tablo tümör hücrelerinin yayılımı ile ilişkilidir. Hastalığın klinik, histopatolojik ve prognozu farklı olan dört ana tipi vardır: Lentigo $M M$, süperfisyel yayılan MM, akral lentijinöz MM, nodüler MM. Palmoplantar bölge, subungual bölge ve mukozalarda yerleşen akral lentijinöz MM, sağlam deride ortaya çıkar ve öncü nevüslerden dönüşüme pek rastlanmaz. Ayak tabanında, özellikle topuk gibi basınca maruz kalan bölgelerde sık yerleşir. Nadiren ayak parmak aralarında da rastlanır (Şekil 7b). Kahverengi, siyah veya mavimsi siyah maküler bir alan şeklinde başlar. Çevreye doğru yayılan, sınırları düzensiz, geniş bir plak halini alır. MM'nin tüm tiplerinde lezyonun tümü veya sonradan ortaya çıkan nodüler bölgesi olmak üzere amelanotik lezyonlar olabilir. Palmoplantar bölgede yerleşen MM'nin ayırıcı tanısında junctional nevüs, verruca plantaris, siyah topuk, ekrin poroma, Kaposi sarkomu ve piyojenik granülom yer alır. Bu bölgede yerleşen nevüsler, asimetri ve pigmentasyon göstererek, MM'yi taklit edebilir. Akral lentijinöz MM, tırnakta yerleştiğinde özellikle ayak başparmaklarını tutar. En sık olarak tırnak matriksinden, daha nadiren de tırnak kıvrımından başlayarak çevreye doğru genişler. Düzensiz pigmentasyon ve tırnak hasarı oluşur. Bir süre sonra tırnağın düşmesiyle, bazen kanama eğilimli olabilen, vejetan bir kitle ortaya çıkar. Subungual bölgede amelanotik melanom da sık görülür. MM'de tanı biyopsi ile konulur. Tedavi cerrahi eksizyondur.

Skuamöz hücreli karsinom (SHK), deri ve mukozalardaki keratinositlerden köken alan, anaplazi, hızlı büyüme, lokal invazyon ve metastaz özellikleri bulunan bir karsinomdur.

Bowen hastalığı, SHK'nin in situ şekli veya öncüsü olarak kabul edilir. Bölgesel infiltrasyon veya üzerinde nodüler gelişim olması SHK açısından uyarıcı olmalıdır. Bowen hastalığı, psöriazis, atopik dermatit veya tinea infeksiyonlarına benzediğinden, papüloskuamöz döküntüsü olan bir hastayı tedavi ederken, lezyon uygun tedaviye yanıt vermiyorsa, mutlaka biyopsi yapılmalıdır. Eğer histopatolojik tanı Bowen hastalığı ise, cerrahi eksizyon veya elektrodiseksiyon ve küretaj ile derin destrüksiyon veya derin kriyoterapi yapılmalıdır veya imikimod kullanılmalıdır.

Değişik nedenlerle oluşan kronik sikatrislerin zeminlerinde SHK gelişme riski vardır. Sikatris üzerinde açıklanamayan indürasyon veya papülonodüler lezyonlar olduğunda biyopsi yapılmalıdır. Marjolin ülseri, Staz ülseri gibi kronik ülserler, kronik sinüsler ve yanık zemini gibi sikatrisyel dokulardan çıkan SHK tipidir. Bu SHK'ların klinik tipi normal deride oluşanlardan farklı olabilir. Sikatris zemininde gelişen SHK'larda metastaz riski normal deriden çıkanlara göre daha fazladır. 
Tedavide cerrahi eksizyon yapılır ancak bazı durumlarda ampütasyon ve radyoterapi de gerekebilir.

Verruköz karsinom, SHK'nın alt grubudur. Yavaş büyüyen, geç metastaz yapan, histopatolojik açıdan iyi diferansiye lezyonlardır. Orta yaş ve üzeri erkeklerde daha sık görülür. Plantar bölgede, özellikle basınca maruz kalan alanlarda yerleştiğinden etyolojisinde travmanın rol aldığı düşünülür. Hiperkeratozik, verrüköz veya vejetan kitleler şeklindedir. Cerrahi sızıntı ve kanamaya neden olabilir. Başlangıçta verruca plantaris'le karıştığından lezyon ilerler. Tanı için derin biyopsi gerekir. Metastaz geç olur ama ihmal edilen lezyonlarda kemiğe kadar invazyon oluşabilir. Cerrahi yöntemle tedavi edilir; radyoterapi anaplastik transformasyona yol açtığından tercih edilmez.

Kaposi sarkomu, başta deri olmak üzere tüm organları tutabilen ve immünsupresyona yol açan durumlara eşlik edebilen neoplastik bir hastalıktır. Etyopatogenezinde HHV-8'in rol aldığı belirtilmektedir. Klasik (Akdeniz), AIDS asosiye (epidemik), Afrika'da görülen (endemik) ve immünsupresyon asosiye (iyatrojenik) tipleri vardır. Hastalığın tüm tipleri, en sık plak şeklinde lezyonlara yol açar. Klasik Kaposi sarkomu, karakteristik olarak ayak derisini tutar (Şekil 9). Sıklıkla Akdeniz ırkından erkeklerde rastlanır. Parmaklar ve ayak tabanı önemli yerleşim bölgeleridir. Akral lezyonların yüzeyi düzgün, hiperkeratozik veya verrüköz olabilir. Erken klinik lezyon piyojenik granülomaya benzer; viyolase, vasküler, sert papül şeklindedir. Tümör büyüdükçe vasküler plak görünümünü alır. Lezyon yavaş büyür ancak tedavi edilmeyen lezyonlar ülsere olur ve kanar. Son dönem tümörlerde bacağı çevreleyen ödem görülür. Tümör, gastrointestinal sisteme de metastaz yapabilir. Geç evrelerde ayırıcı tanıda staz dermatiti (lipodermatoskleroz), hipertrofik liken planus ve derin mantar infeksiyonları yer alır. Ayırıcı tanıda Kaposi sarkomu düşünülüyorsa histopatolojik inceleme yapılması şarttır.

Kaposi sarkomu tanısı konulan hastalara yaklaşımda hastalığın tipi, lezyonların yaygınlığı ve hastanın yaşı önemlidir. Yaşlı hastalarda daha sık görülen klasik tipte, iç organ tutulumu saptanmadığı sürece agresif tedavi tercih edilmez. İntralezyonel sitostatikler (vinblastin, vinkristin) ve düşük doz radyoterapi öncelikli seçeneklerdir. İntralezyonel veya düşük doz alfa interferon da yarar sağlar. Az sayıda lezyon varsa cerrahi uygulanabilir. Agresif tiplerde sistemik kemoterapi gerekebilir.

\section{INFEKSIYONLAR, INFESTASYONLAR}

\section{Bakteriyel deri infeksiyonları}

Paronişi, proksimal ve lateral tırnak kıvrımının infeksiyöz hastalı̆̆ıdır (Şekil 10). Dolama adı da verilen bu tabloda etkilenen bölgede hassasiyet, ISı artışı ve ödem tipiktir. Tedavi edilmezse abse gelişir. Akut ve kronik olmak üzere iki klinik tipi vardır. Akut paronişi gelişiminden sıklıkla S.aureus sorumludur ve ortaya çıkışını kıymık batması ve tırnak yeme gibi minör travmalar kolaylaştırır. Kronik paronişi ise proksimal tırnak kıvrımı ile tırnak plağı arasındaki ayrılma sonucu oluşan boşlukta sıklıkla kandidalara bağı gelişen rekürren seyirli infeksiyondur. Tedavisinde oral ve topikal antibiyotiklerin kullanılması, insizyon ve absenin drenajı gerekebilir.

Büllü distal daktilit, Grup A streptokokların yol açtığı, sıklıkla genç erişkinlerde ve çocuklarda el ve ayak parmaklarının uç bölgelerinde gelişen, içi seropürülan mayi ile dolu gergin bül oluşumuyla karakterize, lokal bir infeksiyondur. Stafilokoklarve Grup B streptokoklar

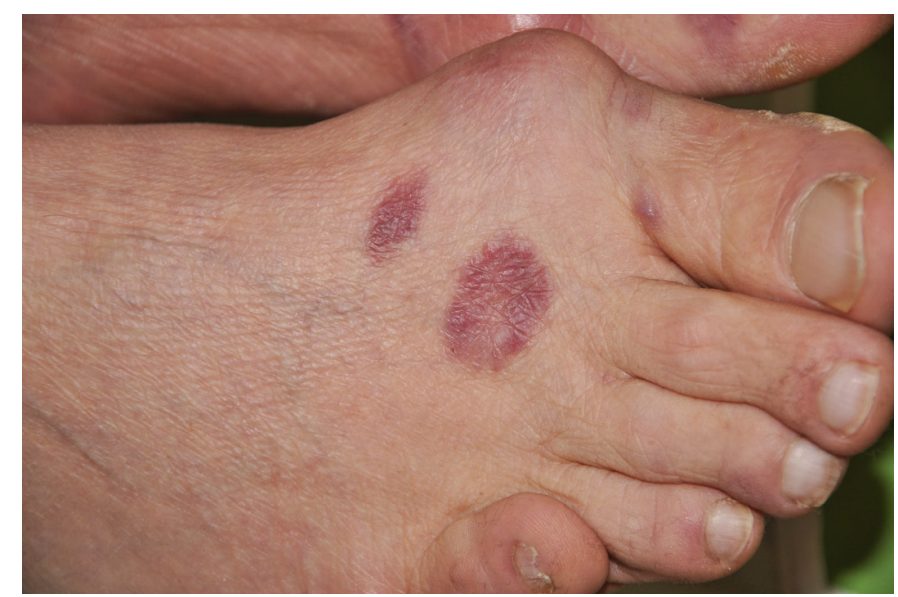

Şekil 9. Kaposi Sarkomu.

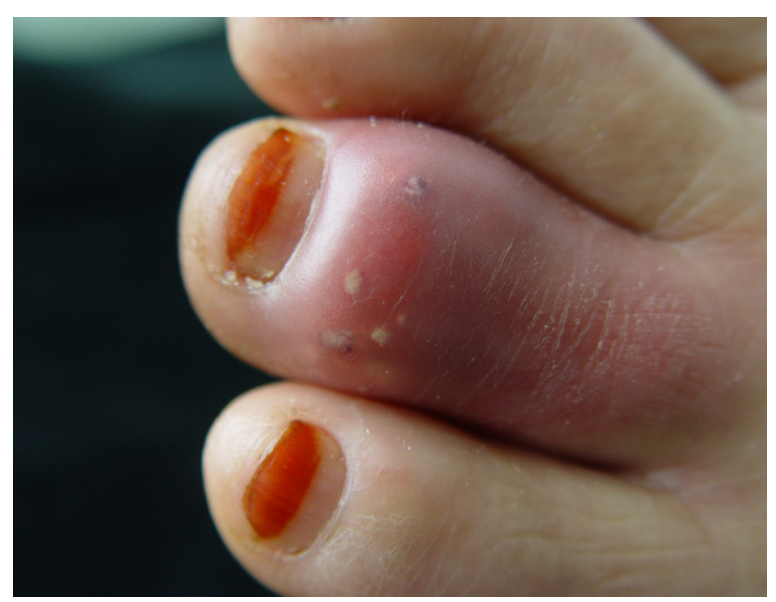

Şekil 10. Paronişi. 
da bu tablonun gelişiminden sorumludurlar. Bül sıvısından yapılan ekimlerde mikroorganizma üretilebilir. Tedavide penisilinler, beta-laktamaz inhibitörleri ve penisilin alerjisi olan olgularda eritromisin kullanılabilir.

Ektima, derinin streptokoksik bir infeksiyonudur. En sık izole edilen ajan Streptococcus pyogenes'tir. Eritemli zeminde küçük bül veya püstül gelişir. Eksüda sıkı yapışık bir krut halini alır. Krutun kaldırılmasıyla zemini pürülan, düzensiz sınırlı ülserasyon görülür. Lezyonlar en sık alt ekstremitelerde ve az sayıda görülür. Otoinokülasyona bağlı yeni lezyon gelişimi olabilir. İyileşme 1-2 haftada sikatris bırakarak olur. Hijyen ve beslenme koşullarının iyileştirilmesi, hastalığa predispozisyon yaratabilecek diğer deri hastalıklarının tedavisi önemlidir. Tedavide streptokok ve stafilokoklara etkili sistemik antibiyotik ve topikal antibakteriyel ajanlar uygulanmalıdır.

Erizipel, dermisin ve subkutan dokunun üst tabakalarının bakteriyel infeksiyonudur. Subkutan dokunun üst tabakalarının tutulumu sonucu ortaya çıkan keskin sınırlı eritemli bir sınırı vardır. Erizipel sıklıkla streptokoksik bir hastalık olarak kabul edilmektedir. Eritem, terleme, ısı artışı, ağrı ve palpasyonla hassasiyet ile karakterizedir. Yüksek ateş ve halsizlik görülür. Erizipele sıklıkla bazen hemorajik olan büller eşlik eder. Interdijital alanları etkileyen bakteriyel ya da mantar infeksiyonları, bacaktaki bir ülserasyon, ayak tabanındaki bir çatlak infeksiyöz ajanlar için giriş kapısı oluşturabilir. Hafif şiddetteki olgularda perioral tedavi verilebilir. Orta ve şiddetli vakalarda streptokoklara ve stafilokoklara yönelik başta beta laktam ve beta laktamaz inhibitörleri olmak üzere, antibiyotiklerin parenteral yolla uygulamaları tercih edilmelidir. Tedavi süresi en az 10 gün olmalıdır. Penisilin alerjisi olanlarda makrolid grubu antibiyotikler tercih edilebilir. Rekürren olgularda uzun süreli penisilin tedavisi uygulanmalı ve infeksiyon için olası giriş kapıları tedavi edilmelidir.

Sellülit, etyolojisinde S.aureus tek başına veya streptokoklarla birlikte rol oynar. İmmünsuprese hastalarda Pseudomonas aeruginosa, Campylobacter jejuni gibi farklı organizmalar da etken olabilir ve bu olgularda sellülit gangrenöz seyredebilmektedir. Eritem, şiddetli olgularda bül ve nekroz gelişebilmektedir. Tedavide, benzatilpenisilin 600-1200 mg iv 4×1, 10 gün süreyle, alternatif olarak klindamisin ve makrolidler kullanılabilir. Rekürren olgularda 500-2000 mg/gün dozunda, atakların önlenmesi için uzun süreli kullanılabilir.

Eritrazma, Corynebacterium minutissimum olarak bilinen aerobik bakterinin neden olduğu, daha çok kıvrım yerlerinde yerleşen, kronik, yüzeyel bir infeksiyondur. Ayak parmak aralarında görülür. Ayak parmak aralarında, düzensiz, keskin sınırlı, başlangıçta kırmızı sonra kahverengi renk alan plaklar, skuam, fissür gelişimi ve maserasyon görülebilir. Genellikle asemptomatiktir, sıcak iklimlerde kaşıntı ve irritasyon görülebilir. Tanı, klinik görünüm ve Wood lambası ile mercan kırmızısı renk görülmesi ile konulabilir. Lezyondan alınan materyalin Gram veya Giemsa boyama ya da $\mathrm{KOH}$ (potasyum hidroksit) ile incelenmesinde bakteri ve ince filamentler gözlenir. Ayak infeksiyonunda bazen Kandida ya da dermatofitlerle birlikte görülebilir. Tedavide Azol grubu antibiyotikler, eritromisin, fusidik asit ve oral yoldan tetrasiklin etkilidir. Kişisel hijyene yönelik antiseptik sabunlar, tedavi sonrası nükslerin önlenmesi için kullanılabilir.

Plantar/Pitted keratolysis, bazı Corynebacterium türleri tarafından oluşturulan, plantar bölgelerde sirküler erozyonlarla karakterli yüzeyel bir infeksiyondur. Nemli iklim, hiperhidroz, kötü hijyen ve uzun süre dar ayakkabı giyilmesi hastalığın ortaya çıkşını kolaylaştırır. Plantar bölge ve ayak parmak fleksör yüzlerinde boynuzsu tabakada çok sayıda küçük, yüzeyel, zımba deliği görünümünde erozyonlar (bal peteği görünümü) izlenir. Bazen yeşil ya da kahverengi görünümde olabilir. Sıklıkla hiperhidrozis, kötü koku ve maserasyon eşlik eder (Şekil 11). Hastaların çoğu asemptomatiktir. Etken $\mathrm{KOH}$ inceleme ile her zaman saptanmaz, Gram boyama ile daha kolay belirlenebilir. Klinik görünüm ile tanı konur. Tedavi amacıyla terleme kontrol altına alındığında belirtiler geriler. Topikal antibiyotikler ve imidazol grubu antimikotikler tedavide etkilidir. Şiddetli olgularda sistemik antibiyotikler (makrolidler) kullanılabilir.

Psödomonas infeksiyonu gelişimine, ayak parmak aralarında dermatofitlerin ya da Gram pozitif bakterilerin inhibisyonu neden olabilir. Keskin sınırı maserasyon, açık yeşil renk ve Wood lambasında yeşil floresans

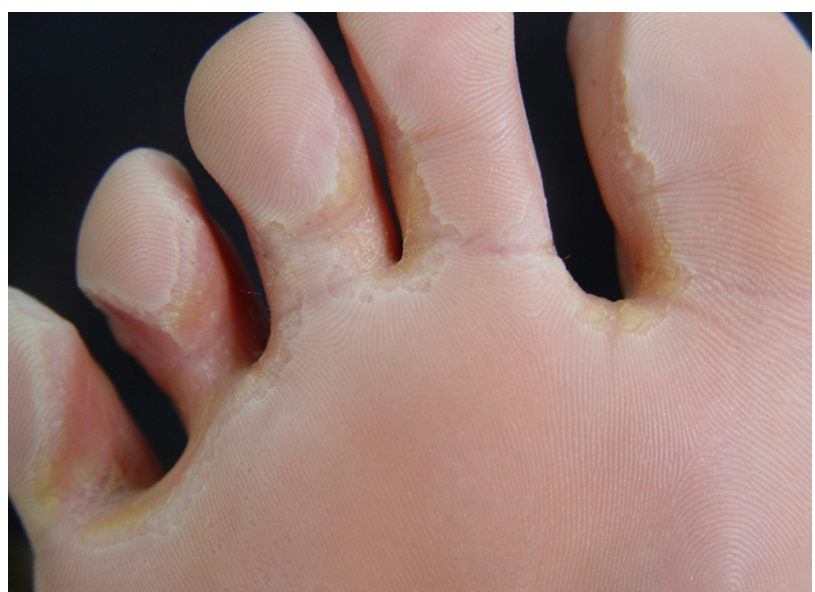

Şekil 11. Pitted keratolysis. 
görülür. Sikatris, sekonder septisemi, ateş ve şok gelişebilir. Tırnak tutulumunda, P.aeruginosa infeksiyonuna bağlı olarak yeşil renkli dikey bantlar görülür. Sıklıkla paronişi eşlik eder. Deri lezyonlarından elde edilen materyalin kültürü ile sorumlu etken üretilebilir. Yüzeyel deri ve parmak arası lezyonlarında ortamın kuruluğu sağlanırsa tedaviye yanıt daha iyidir. Potasyum permanganat, \%1'lik asetik asit, gümüş sülfadiazin krem ve gümüş nitrat günde $2-3$ kez kullanılabilir. Topikal antibiyotiklere yanıt genellikle iyi değildir. Paronişi durumunda cerrahi drenaj yapılmalıdır. Tırnaklara 1-4 ay boyunca, günde birkaç kez, topikal basitrasin ve polimiksin-B uygulaması yapılabilir. Kronik ülserasyon için \%2-5 asetik asit solüsyon etkilidir. Şiddetli infeksiyon ve septisemi durumunda, lezyonlardan kültür alınmalı ve duyarlı antibiyotik tedavisi bir an önce başlanmalıdır. Siprofloksasin, gentamisin, piperasilin, azlosilin, tobramisin, amikasin, seftazidim tek ya da kombine kullanılabilir.

Sifiliz, genellikle cinsel ilişki ile insandan insana bulaşan, deri ve iç organların hemen hepsini tutan, etkeni Treponema pallidum olan, kronik seyirli bir infeksiyon hastalığıdır. Konjenital ve edinsel formaları vardır. Edinsel sifiliz erken dönem, yaklaşık 25-35 günlük kuluçka döneminden sonra Treponema pallidum'un giriş yerinde ortaya çıkan spesifik yara (Şankr sifilitik) ve bu yaradan yaklaşık bir hafta sonra gelişen bölgesel lenfadenopati ile karakterizedir. Şankr iyileştikten sonra başlayan 2. Evre, sifilizin en bulaşıcı evresidir. Bu evrede görülen syphilis papulosa lenticularis, el avuç içi ve ayak tabanlarında mercimek büyüklüğünde, bakır kırmızısı renginde sert papüller halinde gözlenir. Sekonder sifiliz deri lezyonları tedavi edilmeden 1-2 hafta içinde iyileşir; koyu tenlilerde nadiren el avuç içi ve ayak tabanlarında hiperpigmentasyon kalabilir. Klinik ve serolojik testler, karanlık alan mikroskopisi ve gereğinde histopatoloji ile tanı konur. Tedavi hastalığın evresine, yaşına, gebeliğe ve HIV pozitifliğine göre değişmekle birlikte, alerjisi olmayanlarda ilk tercih edilmesi gereken penisilindir.

\section{Viral deri infeksiyonları}

Verrukalar (siğiller), human papilloma virüslerin (HPV) infeksiyonundan kaynaklanan, deri ve mukozaların benin epitelyal hiperplazi ve aşırı keratin üretimi ile karakterize çok sık görülen deri infeksiyonudur. Lezyonlar, deriden kabarık, 3-10 mm çapında, yuvarlak, deri renginde ya da biraz daha koyu renkli, yüzeyi pürtüklü, sert, asemptomatik veya basmakla ağrılı papüller şeklindedir (Şekil $12 \mathrm{a}-\mathrm{c}$ ). Bazen tek, çoğu

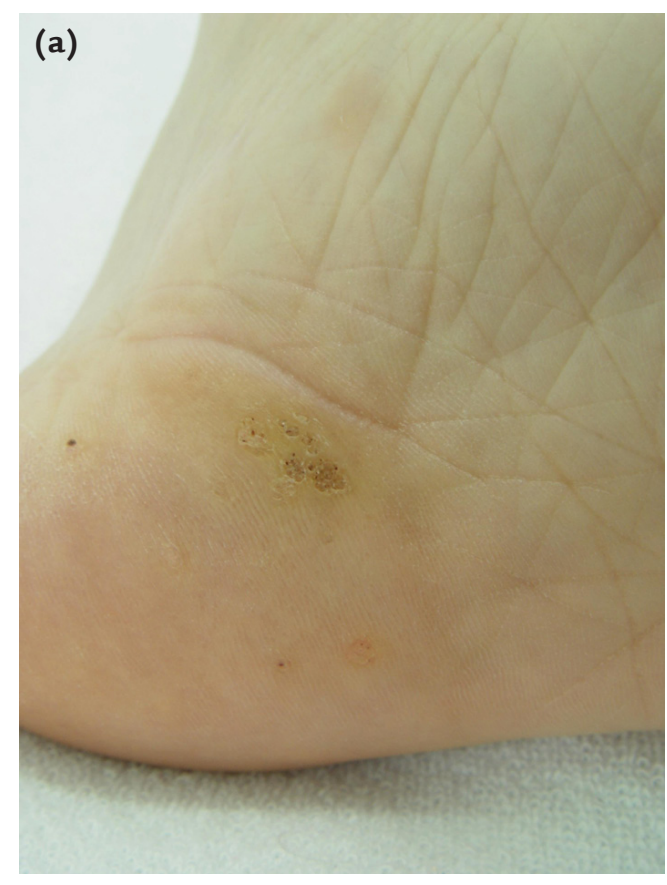

Şekil 12. a-c. Verruca plantaris.
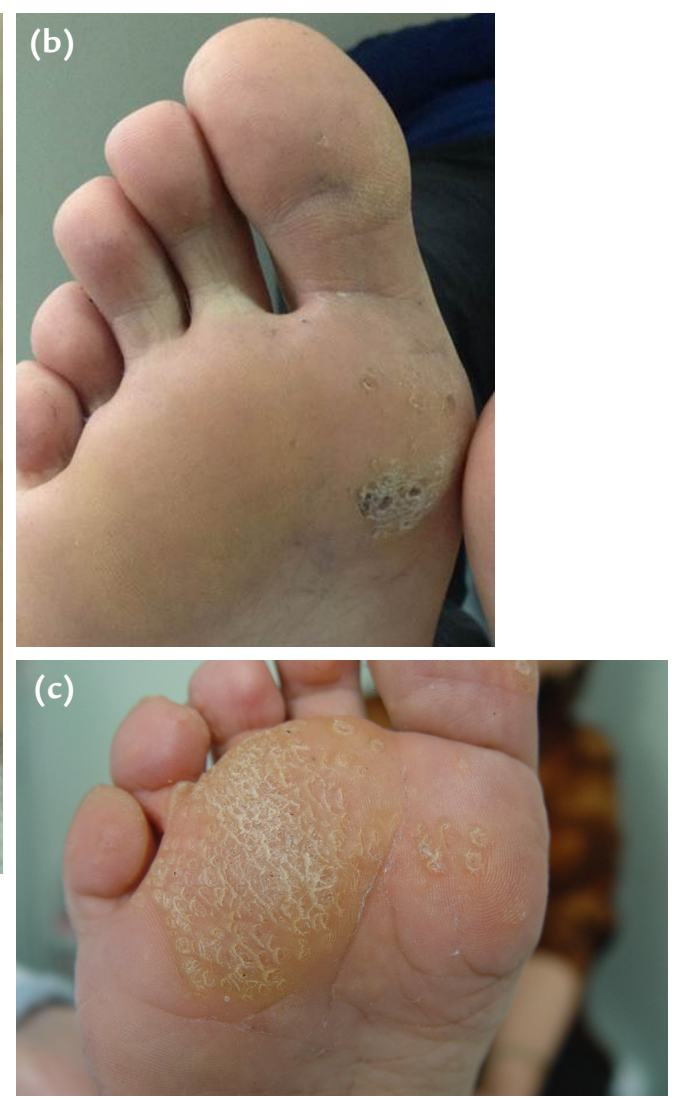
zaman birkaç tane lezyon bir arada bulunur. Illk bulaşma sonrası diğer lezyonlar ekilme yoluyla yayılır. Sadece epidermisi etkilediğinden iz bırakmaz. Hastalara, siğilleri koparmanın çevreye yayılmayı arttırabileceği anlatılmalıdır. İmmünsupresif hastalarda, verrukalar şiddetli seyreder. Çok fazla sayıda lezyon bir araya gelip plak oluşturabilir. Ayak tabanı siğilin sık görüldüğü bir bölge olup, bu bölge lezyonlarına plantar siğil adı verilir. Derin yerleşimlidir. Çoğunlukla birkaç lezyon bir arada görülür ve birleşme eğilimindedir. Bazen kümelenir ve bitişik lezyonlar birleşerek tek lezyon gibi görünebilirler (mozaik verruka). En sık nasır ile karıştırılır. Verrukaların içinde, dermisteki dilate ve tromboze olmuş kapillerlere bağlı siyah kırmızı noktacıklar görülür (Şekil 12b). Bu görünüm ve lezyonlu alanda deri çizgilerinin görülmemesi ile nasırdan ayrılır. Bası bölgelerindekiler ağrıya yol açar. Siğiller, özellikle çocuklarda kendiliğinden gerileyebilmektedir. Kendiliğinden gerilemeyen lezyonlarda, keratolitik etkili kimyasal tedaviler, elektrokoterizasyon, krioterapi, $\mathrm{CO}_{2}$ ve Ndyag lazer gibi destrüktif yöntemler ve immünoterapi kullanılabilir. İmmünsupresif hastalardaki gibi yaygın ve dirençli verrukalarda interferon tedavisi uygulanabilir.

El-ayak-ăğız hastalığı, Coxsackie virus A10, A16 ve Enterovirus 71 ile ilişkili, genellikle kendini sınırlayan, eller, ayaklar, kalçalar ve ağızda veziküler lezyonlarla karakterize akut bir viral infeksiyondur. Nazal ve oral sekresyonlar, fekal materyal ve damlacık yolu ile bulaşır. Hastaların büyük çoğunluğu 10 yaşın altındadır. Hafif ateş, baş ağrısı, boğaz ağrısı, karın ağrısı gibi prodromal belirtileri takiben 2-8 mm çaplı, veziküler lezyonlar oral mukozada ortaya çıkar. Oral lezyonlarla birlikte veya hemen sonra avuç içlerinde, ayak tabanlarında kırmızı renkli papüller hızla çevresi eritemli, küçük grisarı renkli veziküller haline döner (Şekil 13). Veziküller asemptomatik veya ağrılı, hassas olabilir. Lezyonlar bir hafta içinde komplikasyon gelişmeden ve sekel bırakmadan iyileştiğinden semptomatik tedavi yeterlidir.

\section{FUNGAL DERI INFEKSIYONLARI}

Tinea pedis, ayakların çok sık görülen yüzeyel bir dermatofit infeksiyonudur. Kronik intertrijinöz, kronik hiperkeratozik, dizhidroziform ve akut ülseratif tipleri vardır. En sık görülen kronik intertrijinöz tip, çoğunlukla parmak aralarında yerleşir (Şekil 14a). Sıcak ve nemli iklimlerde sıktır. En sık dördüncü-beşinci parmak arasına yerleşir. Parmak aralarında hafif eritem, skuamlar, maserasyon, soyulma ve fissürler görülür. Eritemli, skuamlı plakların keskin ve girintili çıkıntılı sınırı tipiktir. Genellikle kaşıntılıdır ve kötü kokuludur.

Dermatofitler dış ortamda uzun süre canlı kalabildiğinden, infeksiyon özellikle çıplak ayakla gezme

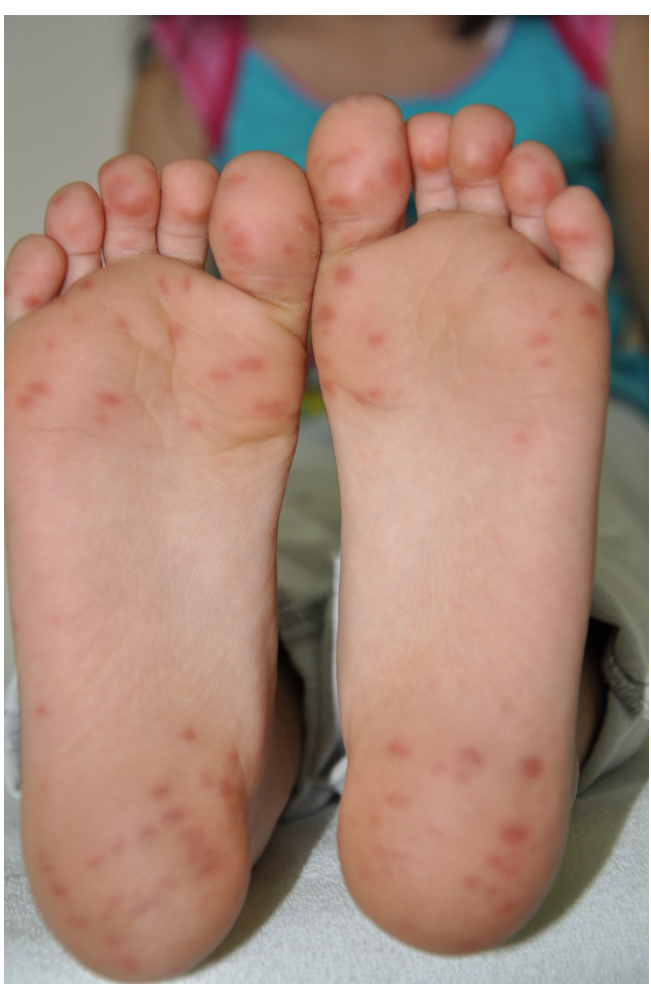

Şekil 13. El-ayak-ağız hastalığı.

sonucu kontamine alanlar ve terliklerden bulaşabilir. Kendi haline bırakılırsa, sekonder bakteriyel infeksiyon ile sellülit-erizipel ve onikomikoz gelişebilir (Şekil 14b). Tedavide, pamuklu çoraplar, rahat ayakkabılar, ayakların iyi kurulanması ve gereğinde alüminyum klorür gibi terleme azaltıcı ilaç kullanımı önerilir; sıklıkla topikal antifungaller yeterlidir.

Hiperhidroz varlığında veya uzun süreli postal giyme gibi terlemeyi arttıran durumlarda, çok şiddetli seyirle geniş alanlarda maserasyon, erozyon ve ülserler oluşabilir; bu durum akut ülseratif tiptir. Ayak tabanı ve ayak yan yüzlerinde yerleşen kuru, hiperkeratozik lezyonlarla seyreden kronik hiperkeratozik tipte (Makosen), onikomikoza sık rastlanır (Şekil 14c). Plantar hiperkeratoz bazen çok şiddetli olabilir. Topikal antifungal tedavi genellikle fazla etkili olmadığından sistemik antifungal ilaçlar (terbinafin, itrakonazol) kullanılabilir. Ayak tabanında yerleşen vezikülobüllöz lezyonlarla karakterize olan dizhidroziform (vezikülobüllöz) tip, çoğunlukla interdijital lezyonlarla beraberdir (Şekil 14d). Genellikle tek ayakta ve sınırlı bölgede yerleşir ancak yaygın da olabilir. Vezikül ve büllerin açılmasıyla erozyon, krut ve skuamlar ortaya çıkabilir. Sekonder bakteriyel infeksiyon eklenebilir. Şiddetli kaşıntı ve yanma yapar. Ellerde id reaksiyonu eşlik edebilir. Ayırıcı tanıya giren dizhidroziform ekzemadan genellikle tek taraflı yerleşmesi ve 

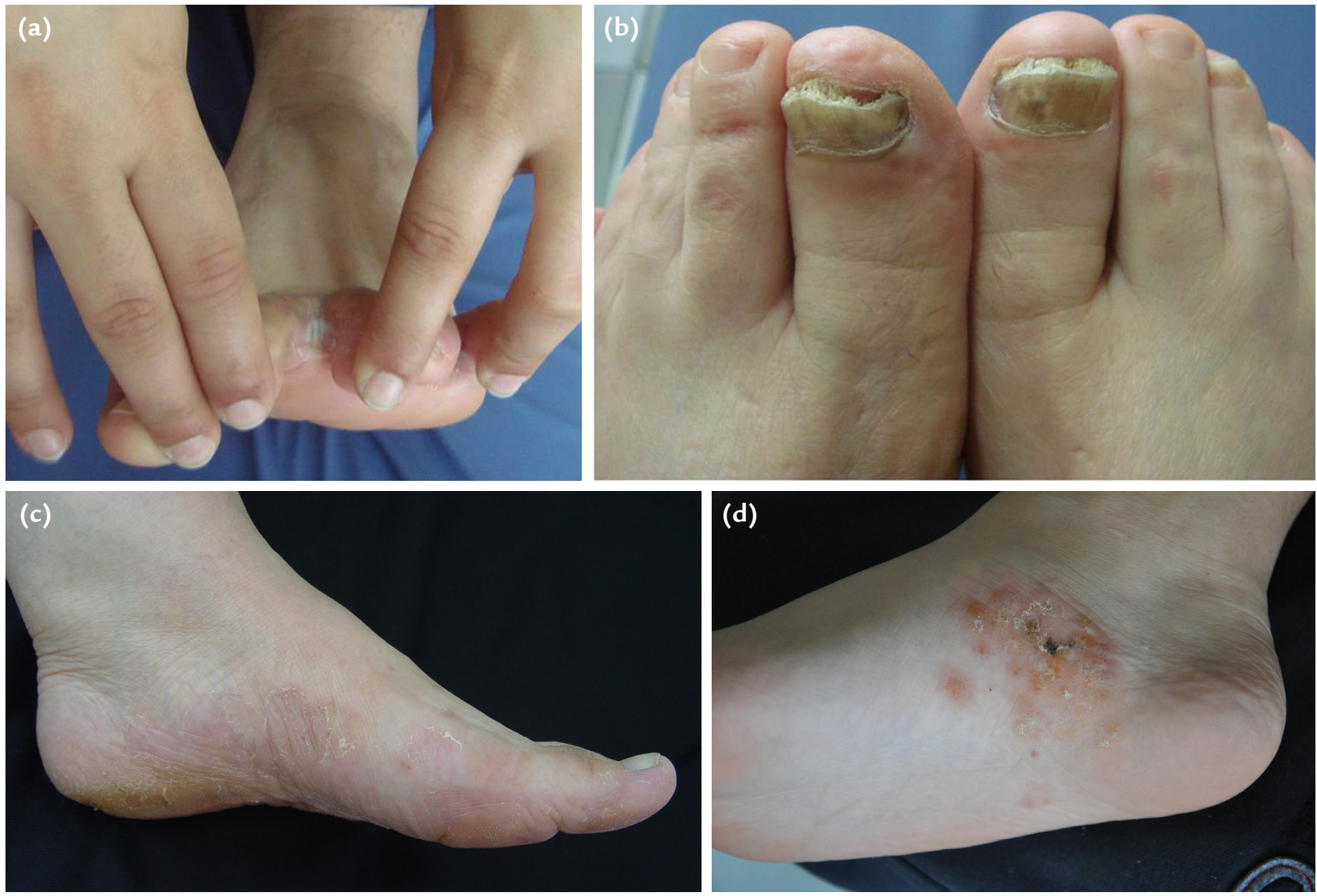

Şekil 14. a-d. Tinea pedis. (a) İntertrijinöz tip. (b) Onikomikoz. (c) Kronik hiperkeratozik tip (Makosen). (d) Dizhidroziform (vezikülobüllöz) tip.

direkt mikroskopide \%10'luk $\mathrm{KOH}$ incelemede hifaların görülmesi ile ayırt edilir. Ancak direkt incelemede pozitiflik oranı düşüktür. Yaygın olmayan lezyonlarda ıslak pansuman ve topikal antifungaller etkilidir.

Ayak üzerinde görülen tinea pedis lezyonları sıklıkla yanlış tanı alır ve immünsupresif ve steroid kullanımı ile karakteri değişebilir.

\section{INFESTASYONLAR-PARAZITOZLAR}

Skabiyez (Şekil 15), etkeni insana zorunlu bir parazit Sarcoptes scabiei var.hominis olan, her yaşta görülebilen bir hastalıktır. Geceleri şiddetlenen, özellikle parmak aralarında başlayan, inatçı kaşıntı ile karakterizedir. Bebek ve küçük çocuklarda, erişkinlerde pek görülmeyen palmoplantar bölge tutulumunda, papül, vezikülopüstül ve bül oluşumu görülebilir. Klinik ve gereğinde deriden kazıntı örneği alınarak yapılan mikroskobik inceleme ile tanı konulur. Tedavide topikal permetrin \%5 krem, gama benzen hidroklorid, benzil benzoat kullanılabilir. Semptomatik olarak antipruritik ilaçlar ve antihistaminikler kullanılabilir.

\section{GENETIK HASTALIKLAR}

Epidermolizis bülloza, doğumdan itibaren veya bir süre sonra travma ve friksiyona uğrayan deri ve mukoza alanlarında bül ve erozyonların ortaya çıkışı ile

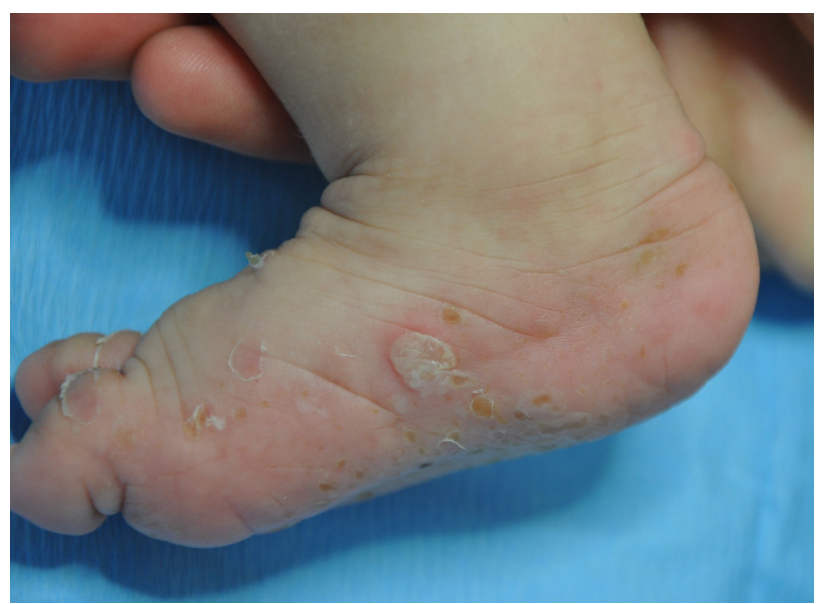

Şekil 15. Skabiyez plantar tutulum. 
kendini gösteren otozomal dominant ve otozomal resesif geçişli herediter bir hastalıktır. Farklı formları vardır. Özellikle ayak sırtı gibi travmaya açık alanlarda, tekrarlayan vezikül ve bül vardır. Ek olarak tırnak, saç, diş ve sistemik tutulum da görülebilir. El ve ayaklarda kontraktür ve yaygın osteoporoz gelişimi olabildiğinden multidisipliner takip edilmesi gereklidir.

Palmoplantar keratodermalar (PPK), el içi ve ayak tabanında aşırı epidermal kalınlaşmayla karakterize bir grup herediter ve akkiz hastalıklardır. Psoriazis invetere, pitriazis rubra pilaris, liken planus, Reiter sendromu, kronik ekzema ve tinea pedis gibi çok sayıda hastalık sekonder olarak palmoplantar hiperkeratoza yol açabilir. PPK, ayrıca idiyopatik olarak veya deri dışı organların da tutulduğu sendromların bulgusu olarak doğumda veya erken yaşlarda ortaya çıkabilir. El ve ayaklar birlikte ve simetrik tutulur. Bazen şiddetli ağrıya yol açarak hastanın hareketlerini kısıtlayabilir. Özellikle obez kadınlarda menopoz sonrası klimakterik keratoderma diye adlandırılan odaksal veya difüz PPK görülebilir. Haxthausen sendromu olarak adlandırılan bu tablo genellikle ayak tabanında, basınç bölgelerinde yoğunlaşan hiperkeratoz ve fissürler ile karakterizedir. PPK ile seyreden herediter tablolar arasında sık görülen Thost-Unna sendromunda lezyonlara hiperhidroz eşlik edebilir. Bu durum maserasyona ve kötü bir kokuya yol açar. Palmoplantar bölgede oluşan ağrılı fissürler en önemli sorundur ve sekonder fungal infeksiyon gelişebilir. PPK'de kesin çözüm sağlayan tedavi yoktur. Yağlı kremler ve keratolitikler kullanılabilir. Ağrılı ve yaşam kalitesini etkileyen lezyonlarda sistemik retinoik asit kullanılabilir.

Knuckle pads, elde interfalangeal ve metakarpofalangeal eklemlerin üzerinde simetrik yerleşen, deriye göre biraz daha koyu renkli, hafif kabarık, keskin sınırlı, sert plaklardır. Proksimal interfalangeal eklem üzerinde daha belirgindir. Etyolojide basınç ve friksiyonun rolü gösterilememiştir. Thost-Unna sendromu, palmar ve plantar fibromatozlarla birlikte olabilir. Tedavide PPK'ye benzer şekilde topikal keratolitik ve yağlı kremler kullanılabilir.

\section{VASKÜLER HASTALIKLAR}

Vaskülit, kan damarlarında immünolojik veya inflamatuvar mekanizmalara bağlı olarak gelişen hasar sonucu ortaya çıkan hastalık grubudur.

Lökositoklastik vaskülit (LkV), küçük damarların (venül) tutulduğu, en sık görülen kutane vaskülit formudur. Sadece deri belirtileri ile seyredebilir veya birlikte sistemik tutulum belirtileri de olabilir. İnfeksiyonlar, ilaçlar, kollajenözler ve bazı kronik hastalıklar neden olabilir. Palpe edilebilen purpura ve hemorajik veziküllerden oluşan döküntü, hastalığın en tipik görünümüdür. Ayak tabanı sık tutulum görülen bölgeler arasındadır. LkV'de üzerinde nekrotik krut bulunan ülserler ve bazen iskemik lezyonlar oluşabilir. Sistemik semptomlar eşlik edebilir. Tanı klinik, histopatoloji ve laboratuvar ile konur. Altta yatan nedene yönelik tedavi, kolşisin, dapson, sistemik steroid, metotreksat veya siklofosfamid kullanılabilir. Birkaç ay içinde sonlanır ama bazen kronikleşir ve nüks görülür.

Livedoid vaskülit (LV) (Şekil 16), ekstremitelerde yaz ve kış aylarında süregelen ülserler ile birlikte olan livedo retikularis benzeri lezyonlar, beyaz atrofik sikatrisler ve histopatolojik olarak segmental hiyalinize vaskülit ile karaketerize olan bir hastalıktır. İdiyopatik veya trombosit fonksiyonu, koagülasyon veya fibrinolitik aktivite bozukluklarında sekonder ortaya çıkabilir. Özellikle bacağın alt bölümü, bilek ve ayakta yerleşir. Peteşi, purpurik papül veya hemorajik büller şeklinde başlayan lezyonlar, kendiğilinden iyileşebilir veya krutla kaplı, ağrılı, küçük ülserlere dönüşebilir. Beyaz, hafif çökük, sikatrisyel lezyonlar da görülebilir. Tanı klinik ve histopatolojik olarak konulur. Tedavide yatak istirahati, fibrinolitik antikoagülan ilaçlar, antitrombolitik ilaçlar, pentoksifilin ve nikotinik asit kullanılabilir.

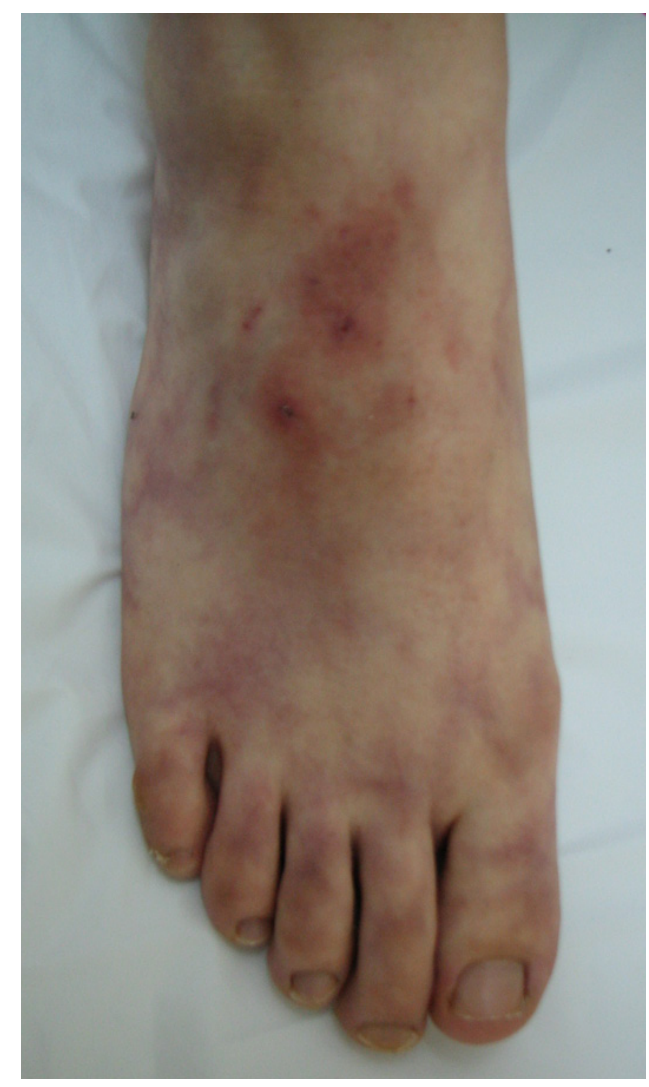

Şekil 16. Livedoid vaskülit. 
Piyoderma gangrenozum (PG), deride nötrofilik infiltrasyon ile seyreden reaktif nötrofilik dermatozlardandır; isminin düşündürdüğü ile çelişkili olarak bir infeksiyon hastalığı değildir. Travma ve operasyon bölgelerinde gelişebilir. Olguların yaklaşık yarısında inflamatuvar barsak hastalığı, hematolojik maliniteler, romatolojik hastalıklar, kronik karaciğer hastalığı ve AIDS gibi hastalıklar eşlik edebilir. Püstüler veya nodüler başlangıç lezyonları, kısa sürede genişleyerek ortalama 8-10 cm çaplı ülsere dönüşür. Ülser zemini, yer yer nekrotik, yer yer hemorajik eksüda ile kaplıdır. Ülserasyon sınırı düzensiz ve keskindir. Derin dermisten yağ dokusu ve fasyaya kadar yayılır. Çoğu zaman şiddetli ağrı, bazen yüksek ateş bulunabilir. Tanı klinik ve histolojik olarak konulur. Tedavide lokal yaş pansumanlar, sekonder infeksiyon varsa antibiyotikler, küçük lezyonlarda topikal veya intralezyonel steroidler, yanıt vermeyen veya şiddetli olgularda sistemik steroidler, siklosporin, azatiopirin gibi ilaçlar kullanılabilir. Debridman ve greftlemeden kaçınılmalıdır.

Kolesterol kristal embolisi (Şekil 17), başta böbrek, deri, bağırsaklar, göz ve merkezi sinir sistemi olmak üzere çok sayıda organ tutulumu ile seyreden ateroembolik bir hastalıktır. Etyopatogenezinde, büyük arterleri çevreleyen aterom plaklarından köken alan kolesterol kristal embolileri yer alır. Antikoagülan veya trombolitik tedavi ve kardiyovasküler cerrahi veya anjiyografi gibi vasküler girişimler, kolesterol kristallerinin dolaşıma katılmasına ve küçük damarlarda emboliye yol açarlar. Periferik nabızlar normaldir. Deride hemen her zaman ayak ve bacaklar tutulur. Çoğu zaman bilateral lezyonlar olur. Alt ekstremitelerde aniden ortaya çıkan bilateral livedo retikularis en sık görülen deri bulgusudur. Akral gangren, parmak uçlarında siyanoza bağlı mavi veya mor renk değişikliği, sert, ağrılı

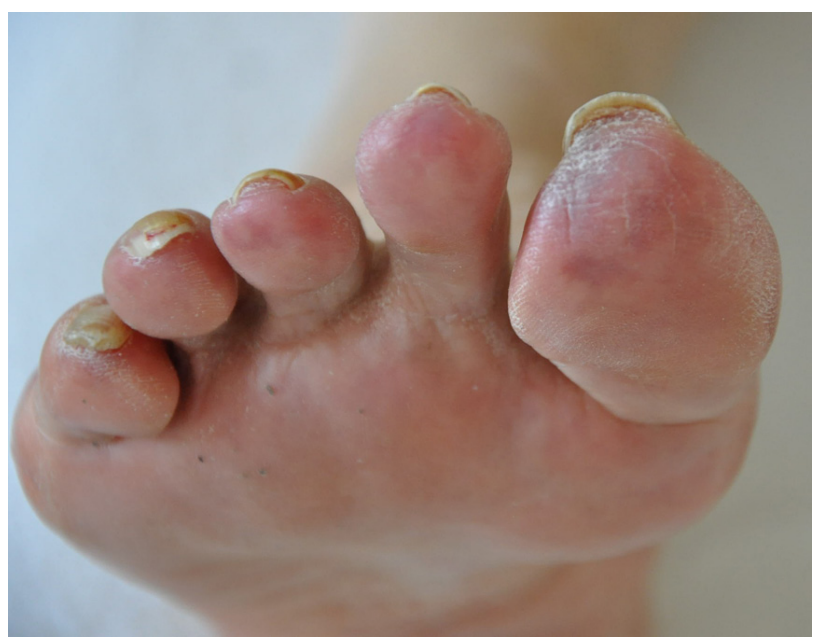

Şekil 17. Kolesterol kristal embolisi. nodüller ve purpura görülebilir. Tanı klinik olarak konulur, histoloji ile desteklenir. Etkin tedavi yoktur, destek tedavi yapılır.

Pigmente purpurik dermatozlar (Şekil 18), klinik özellikleri bazı farklılıklar gösteren ancak ana histopatolojik özellikleri ortak olan, sistemik hastalıklarla ilişkisi bulunmayan, kronik seyirli hastalıklar grubudur. Etyopatogenezde Tip 4 immünolojik reaksiyonla gelişen vasküler hasar ve eritrosit ekstravazasyonu, venöz yetmezlik ve ilaçlar üzerinde durulsa da net değildir. Özellikle alt ekstremitelerde yerleşir. Tipik başlangıç yeri ayak bilekleridir. Zamanla yayılır. Genellikle bilateral, düzensiz sınırı kırmızı maküller, peteşi odakları bulunur. Kırmızı renk zamanla solar ve kahverengileşir. Şiddetli olgularda, bacağın alt kısmında sarımsı kahverengi, difüz renk değişikliği olur. Lezyonların palpasyonla ele gelmemesi ile vaskülitten ayrılır. Çoğu zaman asemptomatik, bazen kaşıntılıdır. Kronik seyir sonrasında kendiliğinden iyileşmeye eğilimlidirler.

Antifosfolipid sendromu, ayaklarda siyanotik maküller, küçük ülserler ve ağrılı nodüllerle seyreden diğer bir trombotik durumdur. Akral ülserasyonlar, şiddetli olgularda gangren ve otoampütasyonla sonuçlanabilir. Tedavide antikoagülan, antiagregan ve immünsupresifler kullanılır.

Kriyoglobulinemi ve kriyofibrinojenemi, özellikle akral bölgelerde, purpura, livedoid lezyonlar, ülser ve nekrozlara yol açar. Kriyoglobulinler ve kriyofibrinojenler, soğukta çöken serum immünglobulinlerdir. Kriyofibrinojenemide, sistemik hastalıklar (malinite, diyabet) gebelik ve oral kontraseptif kullanımı ile ilişkili vardır. Tanı serum kriyoglobulin/kriyofibrinojen artışı ile konur. Kriyoglobulinemi tedavisinde steroid olmayan antiinflamatuvar ilaçlar (NSAii) ve sistemik

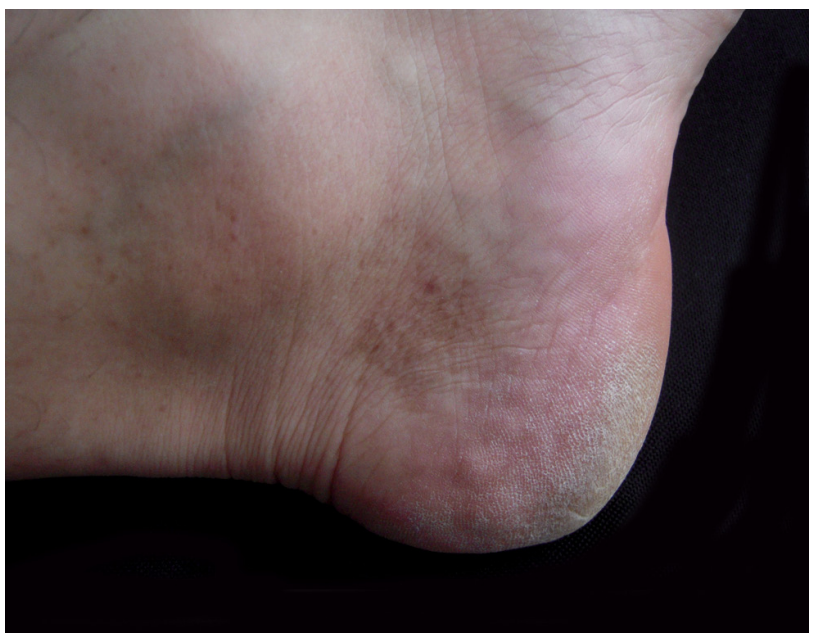

Şekil 18. Pigmente purpurik dermatoz. 
steroidler kullanılabilirken, kriyofibrinojenemide altta yatan nedenin kaldırılması gerekir.

Kronik venöz yetmezlik, derin venleri etkileyen bozukluklar sonucu oluşan, alt ekstremitelerde polimorf deri belirtilerine yol açan, morbiditesi yüksek olan ve sık görülen bir hastalıktır. Perforan venlerin en yoğun olduğu, lateral ve medial malleol bölgeleri başta olmak üzere, bacağın alt kısmında deri belirtileri ortaya çıkar. Venöz basınç artışına bağlı, alt ekstremitelerde, gode bırakmayan ve elevasyonla azalan kronik ödem görülür. Bu zeminde tekrarlayan infeksiyonlar ve travma, subkutan fibrozise yol açar ve deri odunsu sertlikte, indure bir durum alır. Küçük venlerin trombozuna bağlı yağ nekrozu ile subkutan doku kaybı olur. Lipodermatoskleroz olarak adlandırılan bu tabloda, bacağın alt bölümü üste göre incelmiş görülür. Epidermal fonksiyon bozukluğu nedeni ile deri kurudur ve her iki bacak ve ayakta kaşıntı vardır. Akut evrede, ayak bileği iç yüzde en belirgin olan ve tüm alt ekstremiteye de yayılabilen kaşıntılı, eritemli skuamlı yamalar, akut ve şiddetli inflamasyon durumlarında daha eksüdatif, ıslak-nemli yama ve plaklar görülür. Sekonder kapiller dilatasyona bağı oluşan eritem ile dermiste hemosiderin artışına bağlı benekli kahverengi renk değişimi, deri nekrozu sonucu küçük, yassı, düzgün yüzeyli sklerotik plaklar, çok sayıda küçük ülserasyonlar görülür. Venöz yetmezlikte bacak ülseri en sık medial veya lateral malleol üzerinde gelişir (Şekil 19). Topikal antibiyotikli tedaviler ve bandajlara bağlı alerjik kontakt duyarlanma sık görülür. Uzun dönemde, ayak bileğinden dizlere kadar olan bölgede, lipodermatoskleroz, kıllarda dökülme, hiperpigmentasyon ve hiperkeratoz gelişir.

Tedavide öncelikle venöz hipertansiyonun kontrolü, kuruluk ve kaşıntıyı önlemek için nemlendiriciler, akut ekzema dönemlerinde kaşıntıyı azaltmak için topikal steroidler (atrofi yapabileceklerinden kısa dönem, düşük potensliler tercih edilemeli), sulantılı ekzema durumlarında ıslak pansumanlar veya bölgesel banyo tedavileri, gereğinde antiseptikler, topikal veya sistemik antibiyotikler, uygun endikasyonlarda cerrahi tedaviler uygulanabilir.

Periferik arterlerin tıkanması sonucu oluşan, alt ekstremitelerde yerleşen arteriyel ülserasyonların en önemli nedenleri, ateroskleroz, diyabet, Buerger hastalığı, kollajenözler ve arteriyel embolidir. En sık parmak uçları, topuk ve bacağın alt kısmında yerleşir. Yavaş ilerleyici veya ani ortaya çıkar. Epidermal nekrozla başlar, zamanla dermis ve subkutisi tutan kuru gangren halini alır ve kas dokusuna doğru yayılabilir. Keskin sınırı, nekrotik krutla kaplı ülser çok ağrılıdır. Ekstremitelerde soğukluk, parestezi, siyanöz, kıllarda dökülme, tırnak distrofisi ve intermittan klodikasyon

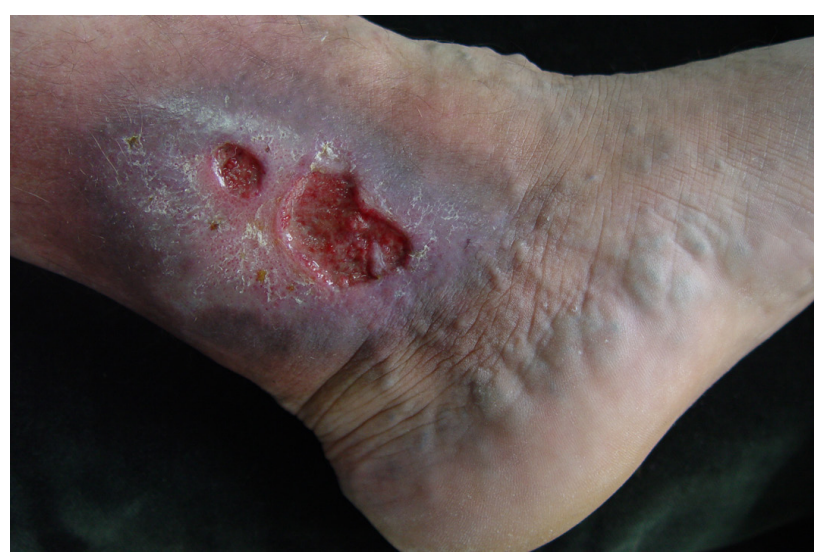

Şekil 19. Kronik venöz yetmezliğe bağlı staz ülseri.

görülebilir. Tanı klinik, Doppler US ve anjiyografi ile konur. Antikoagülan ilaçlar, debridman ve ampütasyon gibi tedaviler dışında, arteriyel tıkanıklığa yönelik cerrahi girişimler de yapılabilir.

\section{MEKANIK HASARLAR}

Pernio (Şekil 20), uzun süre soğuğa maruz kalmaya bağlı akral bölgelerde oluşan inflamatuvar lezyonlarla

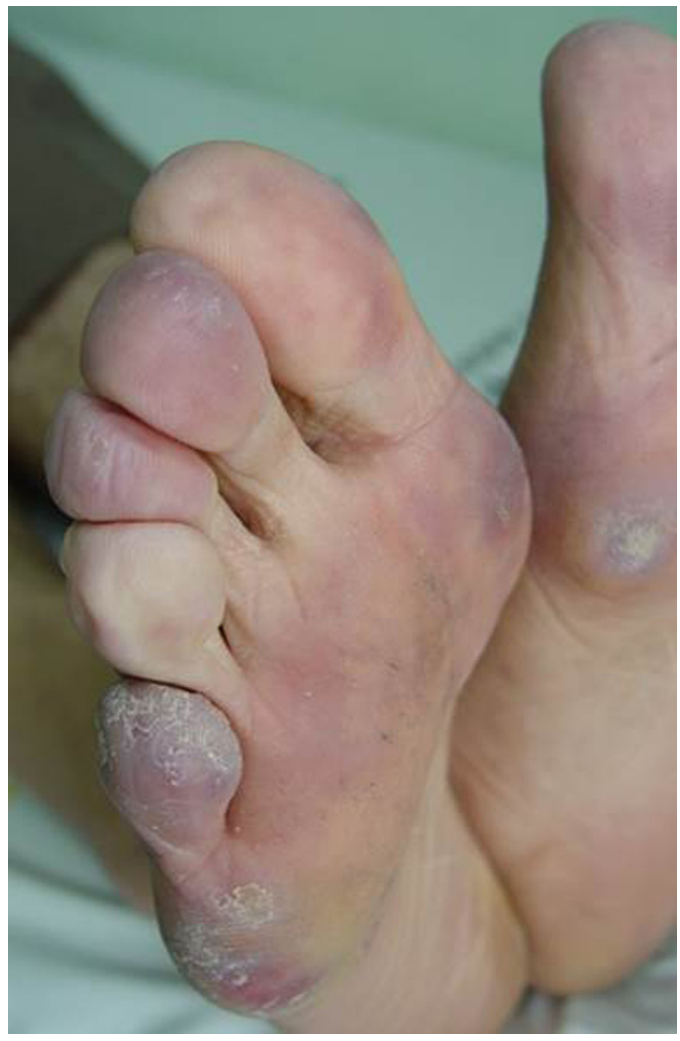

Şekil 20. Pernio. 
karakterize olup, el ve ayak parmaklarının dorsal yüzeyleri ve topukta sık görülür. Genellikle simetrik yerleşimli, mavimsi kırmızı veya mor renkli basmakla solan maküller, hafif kabarık papüller, plaklar ve ödem ile karakterizedir. Şiddetli olgularda bül ve ülserasyon görülebilir. Lezyonlar sıcak havalarda hafifler, soğuğa maruz kalınca tekrarlar. Tanı klinik olarak konur. Tedavide ortamın ısıtılması ve lezyonlu bölgelerin sıcak tutulması yeterlidir.

\section{SISTEMIK VE METABOLIK HASTALIKLARIN DERI BULGULARI}

Diyabetik ayak, diyabet hastalarında nöropati, mikroanjiyopati ve deri kollajen yapısındaki bozulma ile ayaklarda ortaya çıkan deri belirtileridir. Duyu azalması mekanik etkenlere bağlı ülserlerin oluşumunu kolaylaştırır. Bası bölgelerinde ve kallus üzerlerinde ülserler gelişebilir. Arteriyel iskemi sonucu akral ülser, nekroz ve gangren gelişebilir. Sekonder infeksiyon oluşumu sıktır, osteomiyelite neden olablir. Kontrol edilemeyen ülserler ampütasyonla sonuçlanır. Öncelikle kan şekeri regülasyonu, mikroanjiyopati ve nöropatinin tedavisi, infeksiyon kontrolü, yara bakımı ve hastaların ayak bakımı konusunda bilgilendirilmesi önemlidir.

Tendinöz ksantomlar (Şekil 21), Aşil tendonu, el ve ayak sırtının ekstansör tendonları başta olmak üzere, tendon bölgelerinde lokalize, infiltratif, nodüler ksantom tipidir. Bir veya birkaç santimetrelik subkutan nodüller ile karakterizedir. Kan kolesterol düzey artışı ile ilgilidir. Tedavi altta yatan nedene yöneliktir.

\section{SONUÇ}

Ayakta birbirine çok benzeyen, pek çok farklı dermatolojik lezyon görülebilir. Ayak dermatozlarının dermatoloji dışında diğer kliniklerce tam olarak değerlendirilememesi nedeni ile tanı ve tedavide gecikmeler olabilir. Yanlış tedaviler nedeniyle lezyonlar karakter değiştirebilir. Ayak dermatozlarında, hasta ve hekim açısından en doğru yaklaşım, hastalığın dermatoloji kliniği ile multidisipliner değerlendirilmesidir.

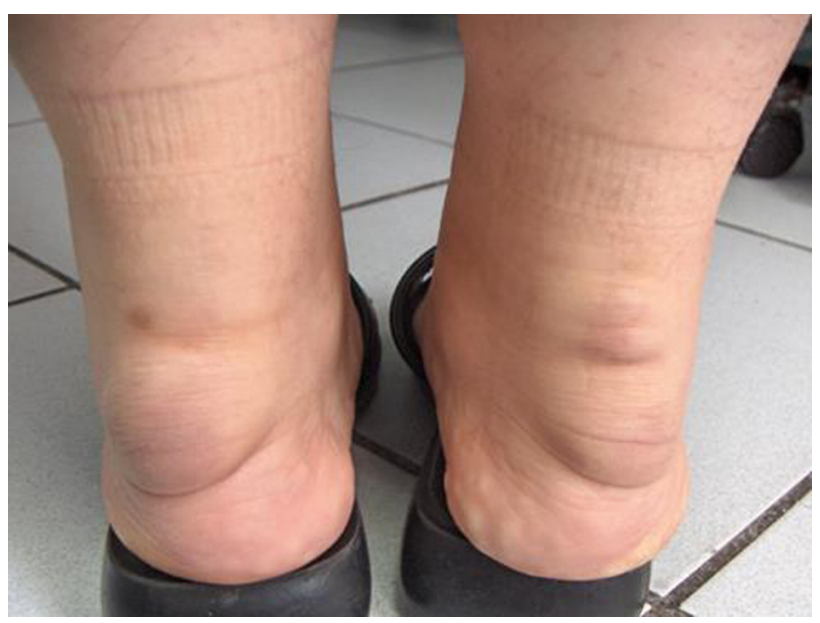

Şekil 21. Tendinöz ksantom.

\section{TEŞEKKÜR}

Makalede kullanılan fotoğraflar, Bakırköy Dr. Sadi Konuk Eğitim ve Araştırma Hastanesi Dermatoloji Kliniği arşivinden alınmıştır.

\section{KAYNAKLAR}

1. Kress DW. Dermatology of the foot and lower extremity In: Coughlin MJ, Mann RA, Saltzman CL. Surgery of the foot and ankle. 8th ed. China: Mosby; 2007. p.1809-23.

2. Baykal C. Dermatoloji Atlası. 2. baskı. İstanbul: Argos; 2004.

3. Bolognia JL, Jorizzo JL, Rapini RP, et al., editors. Dermatology Volume 1-2. 2nd ed. Spain: Mosby Elsevier; 2008.

4. Tüzün $Y$, Gürer MA, Serdaroğlu $S$, Oğuz $O$, Aksungur VL, editörler. Dermatoloji Cilt 1-2. 3. baskı. İstanbul: Nobel Tıp Kitapevleri; 2008.

5. Burgdorf WHC, Plewig G, Wolff $\mathrm{HH}$, Landthaler $\mathrm{M}, \mathrm{O}$ Braun-Falco, editors. Braun Falco's Dermatology. 3rd ed. Heidelberg: Springer; 2009.

6. James WD, Berger TG, Elston DM. Andrews' Disease of the Skin: Clinical Dermatology. 11th ed. China: Saunders Elsevier; 2011. 